\title{
Kainic Acid-Induced Neuronal Death Is Associated with DNA Damage and a Unique Immediate-Early Gene Response in c-fos- lacZ Transgenic Rats
}

\author{
Gary M. Kasof, ${ }^{1,2}$ Allan Mandelzys, ${ }^{1}$ Shanna D. Maika, ${ }^{3}$ Robert E. Hammer ${ }_{,}{ }^{3}$ Tom Curran, ${ }^{1}$ and James I. \\ Morgan" \\ ${ }^{1}$ Roche Institute of Molecular Biology, Roche Research Center, Nutley, New Jersey 07710, ${ }^{2}$ Department of \\ Biological Sciences, Columbia University, New York, New York 10027, and ${ }^{3}$ Howard Hughes Medical Institute, \\ Department of Biochemistry, University of Texas Southwestern Medical Center, Dallas, Texas 75235
}

\begin{abstract}
Previously, we established that persistent upregulation of c-fos expression preceded kainic acid (KA)-induced neuronal death in mice. To discriminate between events that are products of the seizures elicited by KA and those that are specifically associated with its neurotoxic actions, we have examined the expression of cellular immediate-early genes (cIEGs) following KA or pentylenetetrazol (PTZ) treatment in c-fos-lacZ transgenic rats. While both chemoconvulsants elicit seizures, only KA causes selective neuronal death. Following treatment of transgenic rats with KA there was a protracted expression of Fos-lacz that lasted for 2-3 d. In contrast, PTZ elicited a transient increase in the transgene product that lasted about $6 \mathrm{hr}$. Normally, Fos and Fos-lacZ were detected only in neuronal nuclei. However, $6 \mathrm{hr}$ following kainlc acid (but not PTZ) administration, $\beta$-galactosidase activity appeared in the cytoplasm of neurons within vulnerable regions (as determined by the terminal transferase biotinylated-UTP nick end labeling (TUNEL) procedure). Like c-fos, transcripts for other cIEGs were elevated for longer periods in the KA-treated rat hippocampus. In addition, fra-1 and fra-2 were only induced in the KA-treated rat. These changes in mRNA levels were paralleled by a sustained increase in AP-1 DNA binding activity. Thus, quantitative and qualitative changes in AP-1 DNA binding complexes accompany neurotoxic cell death that are not observed following seizures.
\end{abstract}

[Key words: excitotoxicity, pentylenetetrazol, kainic acid, TUNEL, oxidative stress, fos, jun]

Excitotoxicity produced by overstimulation of glutamate receptors has been proposed to play a key role in a number of significant neuropathological disorders including stroke, epilepsy, and Huntington's disease (Rothman and Olney, 1987). Despite the fact that this subject has attracted intense interest, the molecular mechanisms involved in coupling glutamate receptor activation to cell death are incompletely understood. However, there is evidence to indicate that changes in gene expression contribute to this process. For example, protein synthesis inhibitors can attenuate damage in stroke models and they can block

\footnotetext{
Received Oct. 20, 1994; revised Dec, 27, 1994; accepted Jan. 20, 1995

Correspondence should be addressed to Dr. James Morgan at the above address.
}

Copyright 01995 Soctely for Neurascience $0270-6474 / 95 / 154238-12 \$ 05.00 / 0$ glutamate toxicity in vitro and in vivo (Goto et al., 1990; Shigeno et al., 1990; Kure el al., 199 I; Schreiber et al., 1993). The issue, therefore, is to identify which gene products are associated with neuronal death and to establish their role in this process.

A number of studies have shown that cellular irnmediate-early

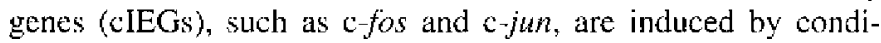
tions that result in the death of neurons (Sonnenberg et al, 1989a; Herdegen et al., 1992; An et al., 1993; Dragunow et al., 1993; Smeyne et al., 1993a,b). Furthermore, cell culture experiments indicate that several cIEGs, notably c-myc, c-fos, c-jun and NGFI-B, may actually contribute to the death process (Askew et al., 1991, Colotta et al., 1992; Evan et al., 1992; Shi et al., 1992; Smeyne et al., 1993a; Liu et al., 1994; Woronicz et al., 1994). The major difficulty in demonstrating an involvement of cIEGs in excitotoxicity is that they are induced by many types of stimuli, the vast majority of which do not lead to cell death. Therefore, we have attempted to assess whether the cIEG response accompanying neuronal death has any unique properties.

Rather than monitor the expression of the entire spectrum of cIEGs we have focused upon members of the Fos and Jun gene families. These proteins contribute, along with other members of the basic-zipper superfamily, to homo- and heterodimeric complexes that can interact with defined DNA elements (reviewed in Morgan and Curran, 1991). Thus, they can contribute to AP-1 (activator protein 1) and CAMP response element binding complexes. It was our interest to determine whether particular, and perhaps unique, AP-1 complexes are associated with excitotoxicity.

Previously we demonstrated the utility of a transgenic mouse line carrying a $c$-fos-lacZ marker gene in the analysis of programmed cell death (Smeyne et al,, 1993a). Here we have extended this approach to a transgenic rat carrying $c_{-}$fos-lacZ. These rats offer a rapid and unambiguous method to follow Fos expression with single cell resolution, while providing sufficient material to permit a rigorous biochemical and molecular genetic analysis of additional AP-I components.

Kainic acid (KA) is a glutamate mimetic that is an agonist for the AMPA/kainate class of glutamate receptor and that induces a cIEG response in vivo (London and Coyle, 1979; Popovici et al., 1988; Sonnenberg et al., 1989a). When administered to rodents, KA initially elicits a period of generalized sei7ures that is followed, hours or days later, by the degeneration of specilic subpopulations of neurons (Nadler et al., 1978; Repressa et al., 1987). To determine the alterations in cLEG ex- 
pression that might be unique to neuronal death, we administered another chemoconvulsant, pentylenetetrazol (PTZ). PTZ, like $\mathrm{KA}$, is known to elicit seizures and induce c-fos expression, but it does not lead to neuronal death (Squires et al., 1984; Morgan et al., 1987; Dragunow and Robertson, 1988; Saffen et al., 1988; Sonnenberg et al., 1989a,b). While one must add the caveat that any differences in the cIEG response elicited by KA or PTZ may reflect the fact that they have distinct mechanisms of action, at a first approximation this permits us to begin the identification of candidate genes that might contribute, either positively or negatively, to neuronal death. Here we establish that there are several features of the cIEG response that are specifically associated with KA treatment.

\section{Materials and Methods}

Production of c-fos-lac $Z$ transgenic rats. The murine $c$-fos-lac $\mathrm{Z}$ fusion gene used to generate transgenic mice has been described previously (Schilling et al., 1991; Smeyne et al., 1992). The linearized DNA was microinjected into fertilized rat oocytes according to published procedures (Hammer et al., 1990). Transgenic rats were identified by Southern analysis of DNA isolated from tail clips using a lac Z probe as described for mice (Smeyne et al., 1992).

Handling of rats. Seizures were induced by intraperitoneal (i.p.) injection of PTZ (55 mg/kg, Sigma) or KA (10 mg/kg, Sigma). Control animals received ip. saline injections $(0.9 \% \mathrm{NaCl})$. At specified time points, animals were anesthetized with sodium pentobarbital $(100 \mathrm{mg} /$ kg, i.p.; Abbott Laboratories) and euthanized.

Preparation of tissue and B-galactosidase histochemistry. Rats were transcardially perfused with $100 \mathrm{ml}$ of saline followed by $500 \mathrm{ml}$ of $3 \%$ paraformaldehyde in $0.1 \mathrm{M}$ PIPES buffer ( $\mathrm{pH}$ 6.9). Following perfusion, brains were dissected, and postfixed overnight in $3 \%$ paraformaldehyde in $0.1 \mathrm{M}$ PIPES containing $10 \%$ sucrose at $4^{\circ} \mathrm{C}$. Tissues were then cryoprotected in $20 \%$ sucrose at $4^{\circ} \mathrm{C}$. For sectioning, tissues were mounted in tissue freezing medium (Triangle Bionedical Sciences) at $-54^{\circ} \mathrm{C}$ and then warmed to $-23^{\circ} \mathrm{C}$. Frozen sections were cut at $20 \mu \mathrm{m}$ and thaw mounted onto Fisher brand premium microscope slides. Sections were then incubated overnight with X-Gal (5-bromo-4-chloro-3indolyl- $\beta$-D-galactopyranosidase; Boehringer Mannheim) to visualize $\beta$-galactosidase activity and counterstained with neutral red (Oberdick et al., 1990).

Terminal transferase biotin-UTP nick end labeling (TUNEL) procedure. For the TUNEL procedure, frozen sections were prepared as for $\beta$-galactosidase histochemistry except that brains were fixed with $4 \%$ paraformaldehyde and slices were $6 \mu \mathrm{m}$ in thickness. Sections were hydrated in $\mathrm{H}_{2} \mathrm{O}$ then rinsed for $5 \mathrm{~min}$. in $10 \mathrm{mM}$ Tris- $\mathrm{HCl}$, $\mathrm{pH} 8$ before incubating for $15 \mathrm{~min}$ with $10 \mathrm{mg} / \mathrm{ml}$ proteinase $\mathrm{K}$ in $10 \mathrm{~mm}$ Tris- $\mathrm{HCl}$, $\mathrm{pH}$ 8. Nonspecific peroxidase staining was eliminated with $3 \% \mathrm{H}_{2} \mathrm{O}_{2}$ for $5 \mathrm{~min}$. Sections were preincubated with terminal transferase (TdT) buffer $(30 \mathrm{~mm}$ Tris base, $140 \mathrm{~mm}$ sodium cacodilate, $\mathrm{pH} 7.2,1 \mathrm{~mm}$ $\mathrm{CoCl}_{2}$ ) for $15 \mathrm{~min}$ at $37^{\circ} \mathrm{C}$. Positive control sections were treated with $2.5 \mu$ I of RQ1 DNase. Subsequently, the sections were incubated with $40 \mu \mathrm{M}$ bio-16-dUTP (Boehringer Mannheim), $0.3 \mathrm{U} / \mu \mathrm{l}$ TdT (IBI/Kodak), in TdT buffer for $2 \mathrm{hr}$ at $37^{\circ} \mathrm{C}$. The reaction was terminated with $2 \times$ SSC and then stained with peroxidase using a Vectastain elite kit (Vector Labs; cat. no. PK-6100 and SK-4100). A qualitative assessment was made by at least two observers.

Hoechst 33258 staining. Morphological evaluations were made using Hoechst 33258 (Molecular Probes). Frozen sections were prepared as for $\beta$-galactosidase histochemistry. Sections $10 \mu \mathrm{m}$ in thickness were stained for $5 \mathrm{~min}$ in Hoechst dye $(1 \mu \mathrm{g} / \mathrm{ml}$ in distilled water $)$, washed in water, and mounted with $50 \%$ glycerol/water. Sections were photographed, and then incubated overnight in X-gal to visualize $\beta$-galactosidase activity.

Isolation of RNA and Northern blotting. Nontransgenic sibling rats were treated with either PTZ or KA. At specified time points, animals were anesthetized with pentobarbital, decapitated, and the hippocampus dissected on ice and frozen in liquid nitrogen. Total RNA was isolated according to the RNAzol method (Biotecx Laboratories Inc.).

Aliquots of total RNA were analyzed by Northern blots according to described procedures (Molinar-Rode et al., 1993). cDNA probes were labeled with ${ }^{32} \mathrm{P}$-dCTP using either the megaprime labeling system (Amersham RPN.1601Y) or nick translation (Amersham N.5000). The probes used have been described previously: c-fos, c-jun, and jun $\mathrm{B}$ (Sonnenberg et al., 1989c); fra-1 (Cohen and Curran, 1988); fosB (Zerial et al., 1989); junD (Ryder et al., 1989); and fra-2 (GenBank accession number U18982).

Preparation of hippocampal nuclear extracts and gel shifts. Hippocampi were dissected and nuclear extracts prepared as described previously (Sonnenberg et al., 1989b).

Gel shift assays were performed using a ${ }^{32} \mathrm{P}$-end-labeled, 20 base double-stranded oligonucleotide corresponding to the AP-1 site of the human collagenase gene (5'-AAGCATGAGTCAGACACCTC-3'; Angel et al., 1987). Binding reactions involved incubating $2 \mu \mathrm{g}$ of hippocampal nuclear extract with $1.4 \mu \mathrm{g}$ of poly $(\mathrm{dI}-\mathrm{dC})$ for $10 \mathrm{~min}$ at room temperature. Approximately $10 \mathrm{~nm}$ of the radiolabeled oligonucleotide was then added and the reaction was allowed to incubate for an additional $10 \mathrm{~min}$. The DNA-protein complexes were resolved on a $5 \%$ nondenaturing polyacrylamide gel in buffer containing $25 \mathrm{~mm}$ Tris base and $195 \mathrm{~mm}$ glycine buffer $(\mathrm{pH} \mathrm{8.5)}$. The gels were dried and the results were visualized by autoradiography. For the competition assays, either a 20 - or 50 -fold molar excess of the designated cold oligonucleotide (mutated collagenase AP-1, 5'-AAGCAGGAGGCAGACACCTC3'; hMT-II , GCCGCAAGTGACTCAGCGCGG-3'; Enk-1, 5'-GATCGCGGGGCTGGCGTAG GG-3') was added to the nuclear extract prior to the addition of the poly ( $\mathrm{dI}-\mathrm{dC}$ ) and was allowed to incubate at $4{ }^{\circ} \mathrm{C}$ for $30 \mathrm{~min}$

\section{Results}

\section{Transgenic Fos-lacZ rats}

Transgenic rats were generated using the c-fos-lac $Z$ fusion gene described previously (Schilling et al., 1991; Smeyne et al., 1992). Since variability can exist between different lines of transgenic animals, offspring from four independent founder rats were analyzed. One line (denoted 1-8) was selected since the localization of the transgene product was similar to that reported using Fos immunohistochemistry in the rat following acute administration of PTZ and KA (Dragunow and Robcrtson, 1988; Popovici et al., 1988; Figs. 1-4 and data not shown). In addition, the basal and stimulated distribution of Fos-lac $Z$ in this transgenic rat closely paralleled that seen in Fos-lacZ transgenic mice (Smeyne et al., 1992; data not shown).

Basal expression of Fos-lac $Z$ was generally low in the brains of untreated rats of the 1-8 line, although sporadic staining was observed in the anterior olfactory nucleus and the cerebral cortex. In animals receiving intraperitoneal injections of saline, a small, transient increase of Fos-lacZ staining was observed (Fig. 1). This staining was most evident in the hippocampus two hours after injection where it was mostly confined to neurons within the CA1 field. This transient induction of Fos-lacZ may be attributed to the stress associated with handling and injecting the animals. Indeed Fos expression has been reported in the CNS, including the hippocampus, following stress (Deutch et al., 1991; Honkaniemi et al., 1992; Kononen et al., 1992; Imaki et al., 1993; Senba et al., 1993).

\section{Influence of $K A$ and PTZ on Fos-lacZ expression}

Within $5 \mathrm{~min}$ of an intraperitoneal injection of PTZ $(55 \mathrm{mg} / \mathrm{kg}$ ) into $\mathrm{c}-f o s-l a c Z$ rats, clonic-tonic seizures were observed that lasted approximately $10 \mathrm{~min}$. Expression of Fos-lacZ was not detectable in the hippocampus at 30 min following PTZ treatment, but it was highly induced by $2 \mathrm{hr}$ (Fig. 2). With the exception of CA2, expression of $\beta$-galactosidase was seen in most neurons of the hippocampus where it was confined to the nucleus. Fos-lacZ staining decreased markedly by $6 \mathrm{hr}$ and was absent by $24 \mathrm{hr}$ postinjection. Besides the hippocampus, PTZ induced expression of the transgene in the anterior olfactory nucleus, caudate putamen, and frontal, pyriform and cingulate cortices (data not shown). 

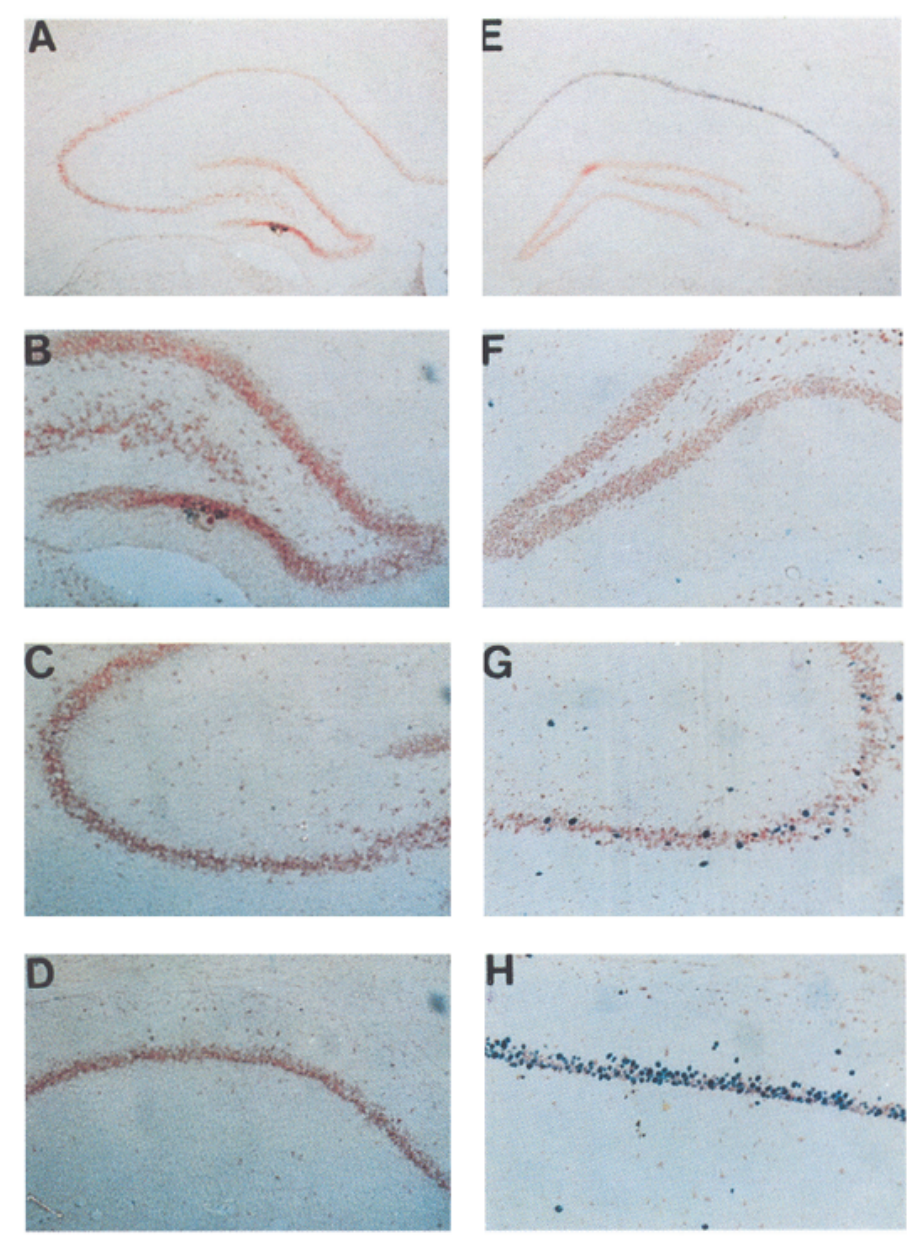
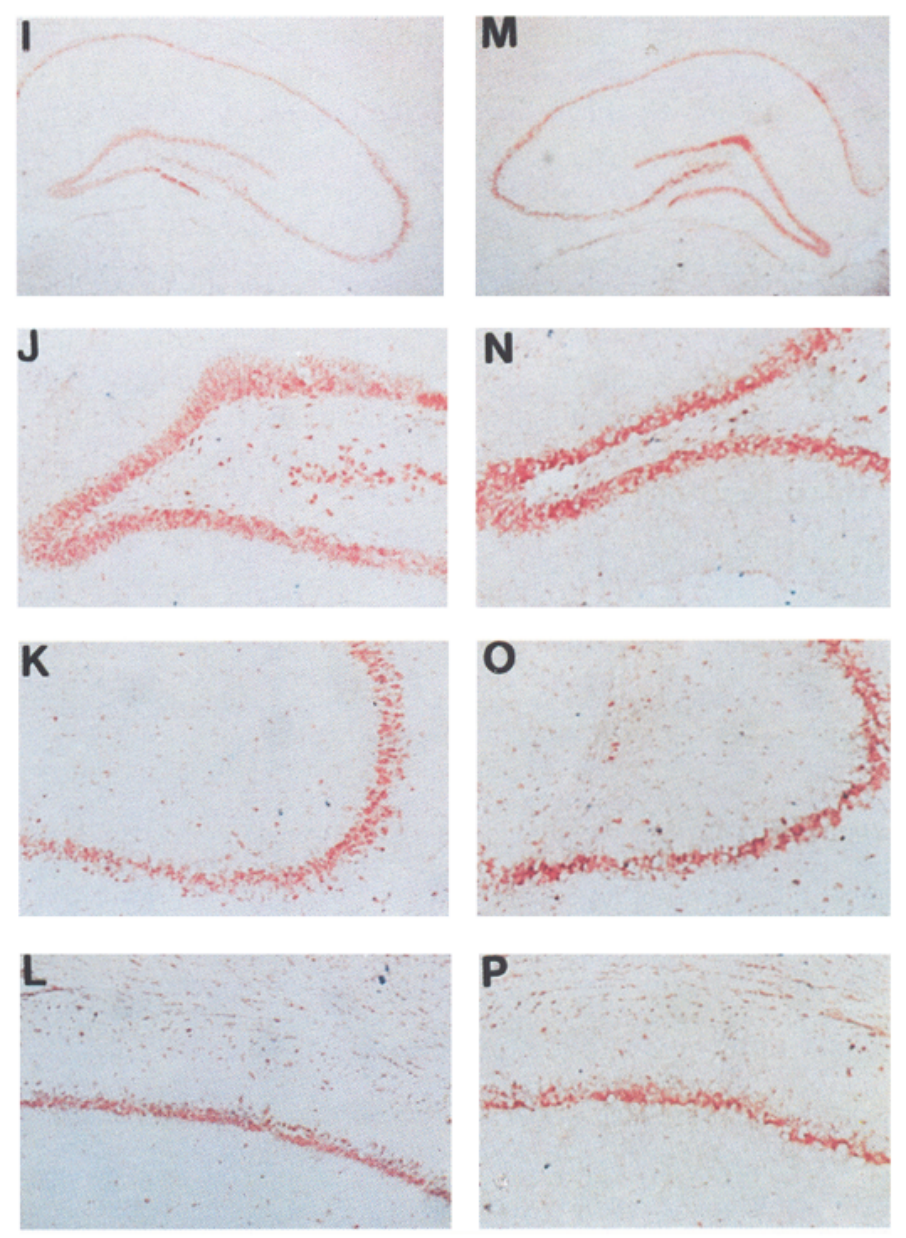

Figure 1. Time course of Fos-lacZ expression in the hippocampus of transgenic rats following saline injection. c-fos-lacZ transgenic rats were given an intraperitoneal injection of saline $(1 \mathrm{ml} / \mathrm{kg})$ and sacrificed at $0(A-D), 2(E-H), 6(I-L)$, and $24 \mathrm{hr}(M-P)$ following treatment. A transient increase in $\beta$-galactosidase activity was observed in CA1 pyramidal neurons while a few neurons within CA3 were also induced. Shown here are the hippocampus $(A, E, I, M)$, dentate gyrus $(B, F, J, N)$, CA3 $(C, G, K, O)$, and CA1 $(D, H, L, P)$. Magnification: $4 \mathrm{X}$ for $A, E, I$, and $M ; 10 \mathrm{X}$ for $B-D, F-H, J-L, N$, and $O$.

Compared to PTZ, intraperitoneal injection of $\mathrm{KA}(10 \mathrm{mg} / \mathrm{kg})$ elicited a delayed but protracted behavioral response. Overt evidence of seizures first became apparent approximately $1 \mathrm{hr}$ after injection of KA and increased in severity over the next $2-3 \mathrm{hr}$ as the animals entered into status epilepticus. After $3 \mathrm{hr}$ the intensity of the seizures waned and the animals appeared exhausted. Occasionally, seizures recurred upon subsequent handling of the rats.

Two hours following administration of KA, a large induction of Fos-lacZ was observed throughout the hippocampus in a pattern similar to that seen with PTZ (Fig. 3). However, in contrast to PTZ-treated rats, Fos-lacZ expression increased further by 6 hr post KA treatment. Furthermore, by $6 \mathrm{hr}, \beta$-galactosidase activity began to appear in the cytoplasm of neurons located in $\mathrm{CA} 1$ and $\mathrm{CA} 3$, a finding never encountered following treatment with PTZ. After $24 \mathrm{hr}$, extensive cytoplasmic $\beta$-galactosidase activity was observed in CA1 and CA3, a time when there was no detectable Fos-lacZ expression in PTZ-treated rats. In addition to the hippocampus, cytoplasmic Fos-lacZ was also detected in the pyriform cortex (Fig. 4), the anterior olfactory nucleus and cingulate cortex (data not shown). We have previously reported the presence of cytoplasmic Fos-lacZ in the hippocampus of kainic acid-treated mice (Smeyne et al., 1993). Also consis- tent with these observations is the finding by Popovici et al. (1988) of faint cytoplasmic Fos-like immunoreactivity in rat hippocampal pyramidal neurons following administration of KA.

Previously, it was demonstrated that barbiturates block seizure activity and cIEG induction in the mouse (Morgan et al., 1987; Sonnenberg et al., 1989a). Similarly, the cIEG response in the rat elicited by KA was blocked by the barbiturate, sodium pentobarbital (data not shown). Furthermore, a nonconvulsant dose of $\mathrm{KA}(7.5 \mathrm{mg} / \mathrm{kg})$ did not cause a cIEG response (data not shown). This indicates that the mere presence of KA is not sufficient to elicit this response but that it requires seizure activity.

\section{Expression of cIEGs following $K A$ and $P T Z$ treatment}

To confirm the protracted expression of c-fos and to identify other gene products that might contribute to gene regulatory events following seizures, mRNA levels of other cIEGs were analyzed in PTZ- and KA-treated rat hippocampus. Of particular focus was the expression of genes that encode proteins related to Fos or Jun; namely fra-1, fra-2, fos B, jun B and junD.

Both PTZ and KA induced a cIEG response in rat hippocampus as determined by Northern blot analysis (Fig. 5). However, there were a number of differences between the responses elicited by the two chemoconvulsants. Some of these differences 

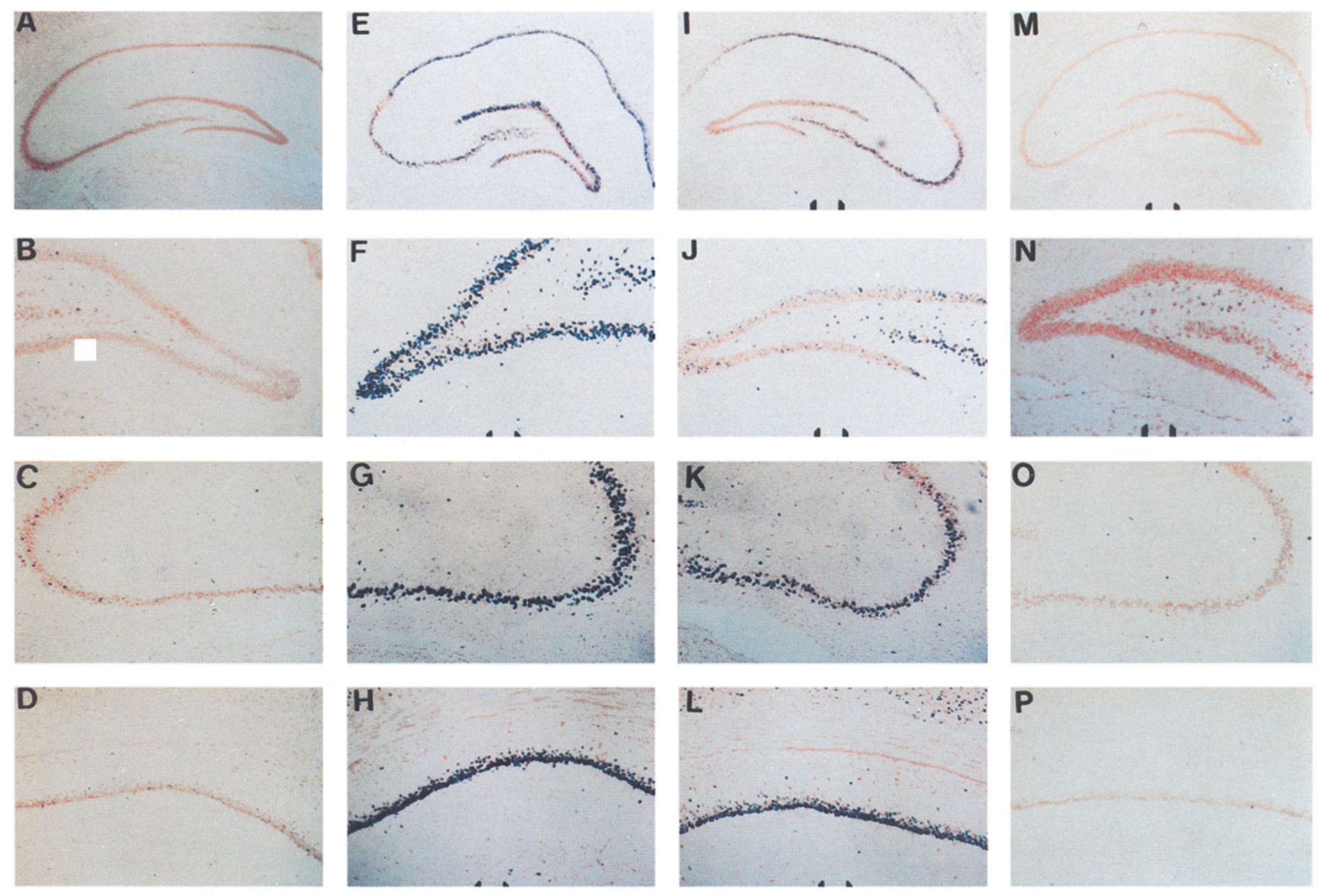

Figure 2. Time course of Fos-lacZ expression in the hippocampus of transgenic rats following PTZ treatment. Seizures were induced in c-foslacZ transgenic rats by intraperitoneal injection of PTZ $(55 \mathrm{mg} / \mathrm{kg})$. Rats were sacrificed at $0.5 \mathrm{hr}(A-D), 2 \mathrm{hr}(E-H), 6 \mathrm{hr}(I-L)$, and $24 \mathrm{hr}(M-P)$ following treatment. A transient increase in $\beta$-galactosidase activity was observed throughout the hippocampus. Shown here are the hippocampus $(A, E, I, M)$, dentate gyrus $(B, F, J, N)$, CA3 $(C, G, K, O)$, and CAl $(D, H, L, P)$. Magnification: $4 \mathrm{X}$ for $A, E, I$, and $M ; 10 \mathrm{X}$ for $B-D, F-H, J-$ $K, L$, and $N-P$.

were anticipated based upon the time course of the behavioral responses to the two agents. For example, the delayed onset of seizures in KA-treated, compared to PTZ-treated, rats is associated with a delayed rise in cIEG mRNA levels in the former. Furthermore, the more intense and extended period of seizures in KA-treated animals was paralleled by alterations in cIEG mRNA levels that were in general of greater magnitude and duration than in PTZ-treated rats. For example, following PTZ treatment, cIEG mRNA levels were highest at $30 \mathrm{~min}$, declined markedly by $2 \mathrm{hr}$ and were absent at $6 \mathrm{hr}$. In contrast, following $\mathrm{KA}$ administration cIEG mRNA levels were not elevated at 30 min, rose dramatically at $2 \mathrm{hr}$ and $6 \mathrm{hr}$ and were still well above baseline at $48 \mathrm{hr}$ posttreatment. These results provide an independent confirmation of the data obtained in the $\mathrm{c}-f o s-l a c \mathrm{Z}$ rats.

From a qualitative perspective, there were differences between the responses of individual cIEGs to KA and PTZ. Thus, the expression of several cIEGs was only detected in KA-treated rats. For example, c-jun, fra-1, and fra-2 transcripts were only robustly elevated by KA. Interestingly, in the case of fra-2, only the larger transcript was persistently elevated. Although fra-1 is a cIEG, its induction in fibroblasts is delayed in respect to c-fos and c-jun (Cohen and Curran, 1988). Here a similar temporal relationship is observed for fra-1. Several cIEGs showed sus- tained elevation, such as c-fos and $j u n \mathrm{~B}$, although others increased and declined to baseline within $24 \mathrm{hr}$ (e.g., fos B). Finally, junD mRNA levels were not altered by either agent, indicating that it might be a constitutive component of AP-1 complexes in the hippocampus. In some cases a biphasic induction of cIEGs was observed. For example, c-fos and junB levels declined between 6 and $24 \mathrm{hr}$ and then increased again. On the other hand, c-jun, fra-1, and fra-2 exhibited a single phase of induction.

\section{Characterization of AP-1 activity in KA-treated rat brain}

The Northern blot data suggested that mRNA levels for many cIEG products that can contribute to AP-1 (and related) DNA binding complexes were elevated prior to neuronal death in the hippocampus. However, with the exception of Fos-lacZ expression, there was no independent proof that these mRNAs were translated into proteins. This is not a trivial point since inhibition of protein synthesis leads to an upregulation of cIEG mRNA levels (Muller et al., 1984). Furthermore, some neuropathological states, such as cerebral ischemia, are associated with compromised protein synthesis, which has led to confusing results regarding cIEG expression (Thilman et al., 1986; Kogure et al., 1987; Dragunow et al., 1993). Therefore, to demonstrate the 
A
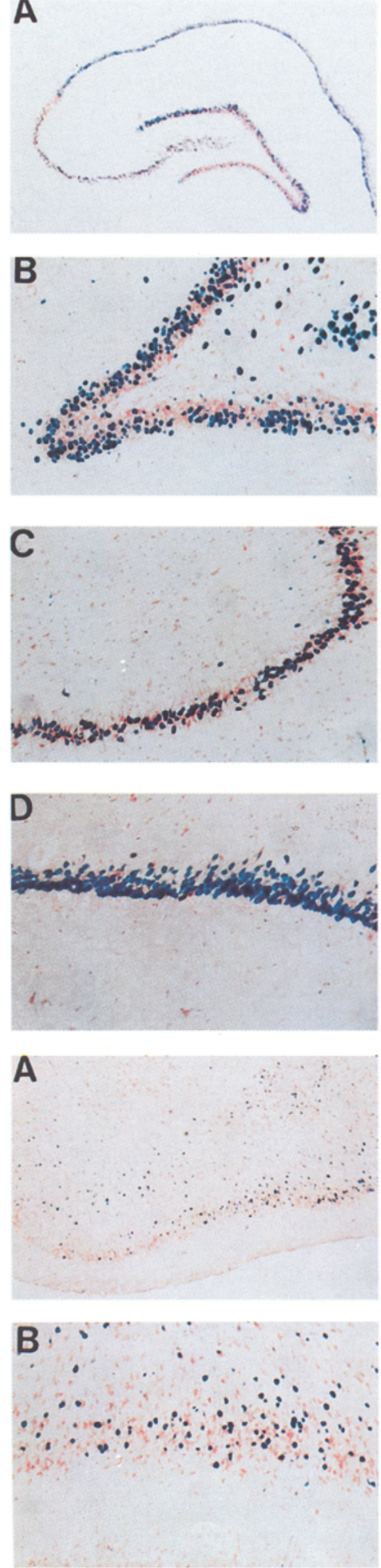
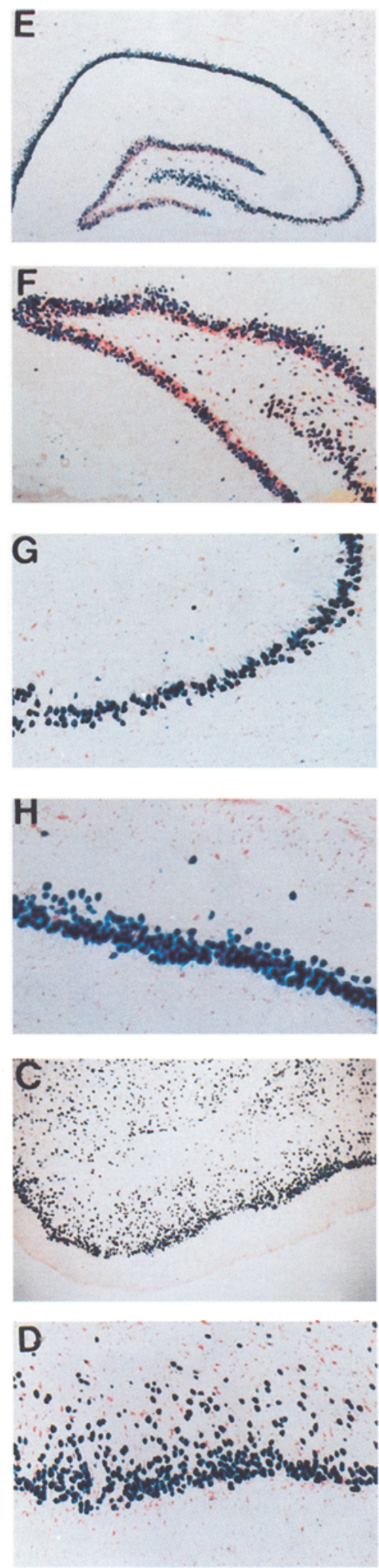
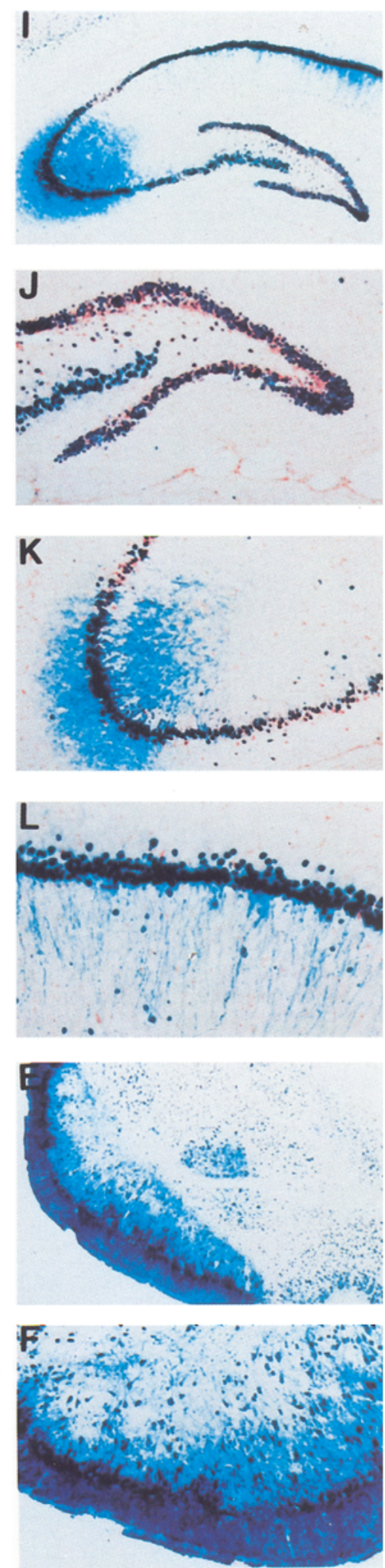

Figure 3 (top). Time course of Fos-lacZ expression in the hippocampus of transgenic rats following KA treatment. Seizures were induced in c-fos-lacZ transgenic rats by ip. injection of KA $(10 \mathrm{mg} / \mathrm{kg})$. Rats were sacrificed at $2(A-D), 6(E-H)$, and $24 \mathrm{hr}(I-L)$ following treatment. A sustained increase in $\beta$-galactosidase activity was observed throughout the hippocampus. Cytoplasmic staining began to appear $6 \mathrm{hr}$ following $\mathrm{KA}$ treatment in pyramidal neurons within CA $3(G)$ and CA1 $(H)$ and was more abundant at $24 \mathrm{hr}(K, L)$. Shown here are the hippocampus $(A, E, I)$, dentate gyrus $(B, F, J), \mathrm{CA} 3(C, G, K)$, and CA1 $(D, H, L)$. Magnification: $4 \mathrm{X}$ in $A, E$, and $I ; 10 \mathrm{X}$ in $B-D, F-H$, and $J-L$.

Figure 4 (bottom). Time course of Fos-lacZ expression in the pyriform cortex of transgenic rats following KA treatment. Seizures were induced in c-fos-lacZ transgenic rats by intraperitoneal injection of KA $(10 \mathrm{mg} / \mathrm{kg})$. Rats were sacrificed at $2(A$ and $B), 6(C$ and $D)$, and $24 \mathrm{hr}(E$ and $F$ ) following treatment. A sustained increase in $\beta$-galactosidase activity, with leakage into the cytoplasm, was observed in the pyriform cortex. Magnification: $10 \mathrm{X}$ in $A, C$, and $E ; 20 \mathrm{X}$ in $B, D$, and $F$. 


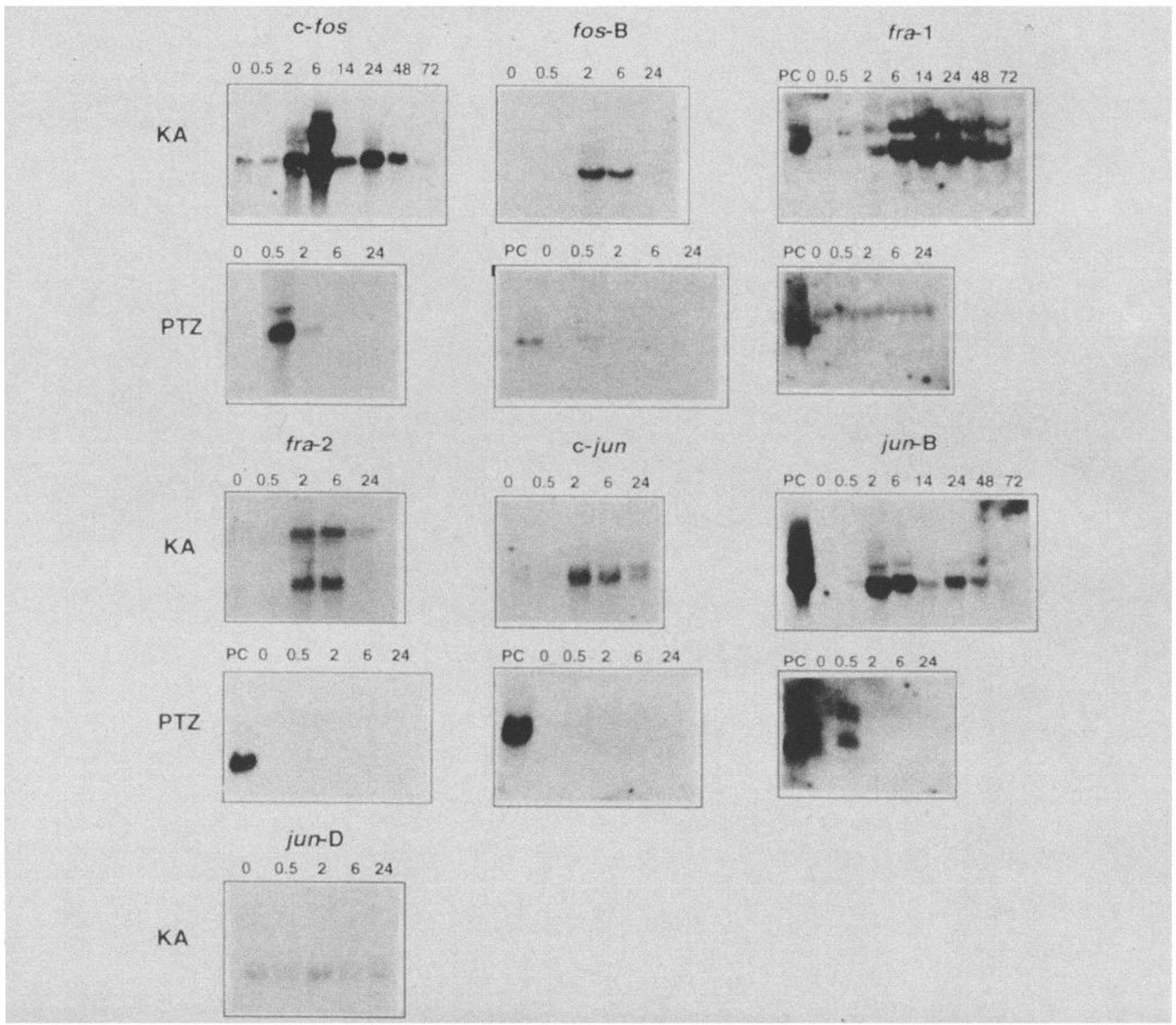

Figure 5. Northern blots comparing immediate-early gene responses to PTZ and KA in the rat hippocampus. Total RNA was isolated from dissected hippocampi of rats treated with either PTZ $(55 \mathrm{mg} / \mathrm{kg})$ or KA $(10 \mathrm{mg} / \mathrm{kg})$ for various lengths of time. (Times, in hours, following treatment are indicated.) $P C$ represents a positive control RNA (liver RNA from a cycloheximide-treated mouse). Blots were probed for c-fos, fos $\mathrm{B}$, fra-1, fra-2, c-jun, jun B, and jun D as indicated; $10 \mu \mathrm{g}$ total RNA/lane was loaded and overall loading and transfer efficiency was monitored by ethidium bromide staining and GADPH levels.

presence of AP-1 DNA binding complexes, gel retardation analyses were performed on crude nuclear extracts from control and KA-treated rat hippocampi.

After administration of KA, there was an increase in AP-1 binding activity present in hippocampal nuclear extracts (Fig. 6). Increased binding was evident by $2 \mathrm{hr}$, peaked at $6 \mathrm{hr}$ and was still above baseline $3 \mathrm{~d}$ later. Interestingly, two distinct AP-1 bands displayed different kinetics of activation. Binding specificity of both bands was shown by competition by the cognate AP-1 oligonucleotide but not by a mutated oligonucleotide that does not have AP-1 activity (Fig. 6). The more rapidly migrating complex persisted for at least $3 \mathrm{~d}$ in the hippocampus of KAtreated rats while the slower migrating species returned to baseline levels between 1 and $2 \mathrm{~d}$ posttreatment. The rapidly migrating band is reminiscent of the persistent AP-1 activity observed by Nestler and colleagues in rats that had received re- peated administration of cocaine (Hope et al., 1992). These results confirm and extend the Northern blot data and demonstrate that among the sequelae of kainic acid treatment is a protracted increase in components of AP-1 DNA binding complexes.

\section{DNA damage in hippocampal neurons induced by $K A$ treatment}

$\mathrm{KA}$ is known to cause the death of neurons in the rat hippocampus (Nadler et al., 1978; Represa et al., 1987). This is confirmed by the loss of cytotechtonic order in the hippocampi of KAtreated transgenic rats (Fig. 3). Thus, the presence of Fos-lacZ in the cytoplasm of CA1 and CA3 neurons appears to be a marker of their impending demise. However, the nature of the relationship between Fos-lacZ expression and death is still unknown. Furthermore, the differential expression of some cIEGs 
$\mathbf{A}$

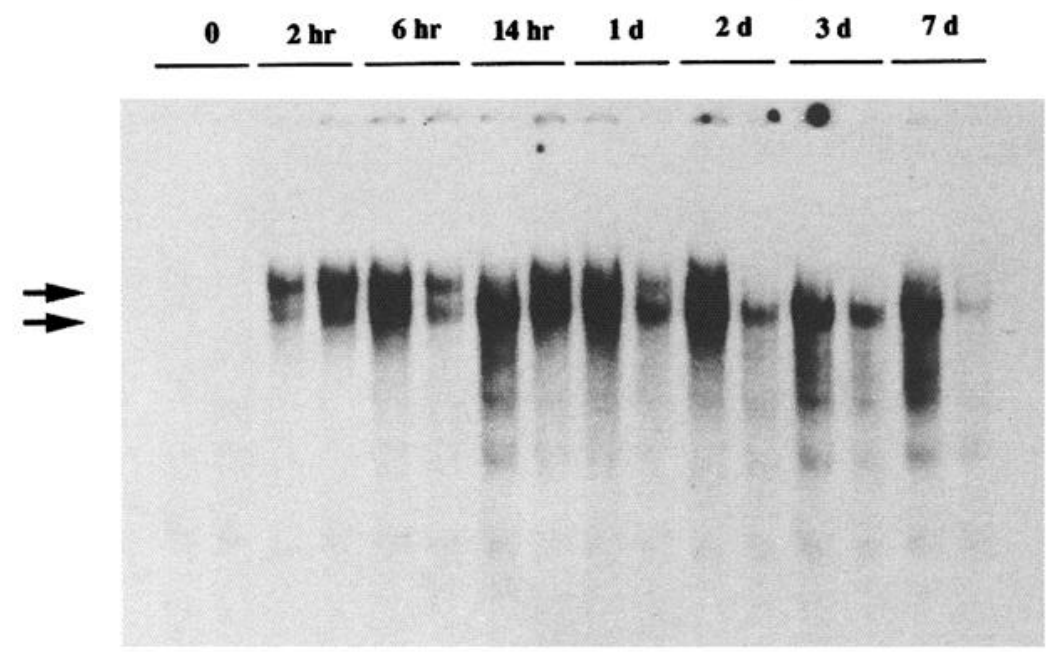

B

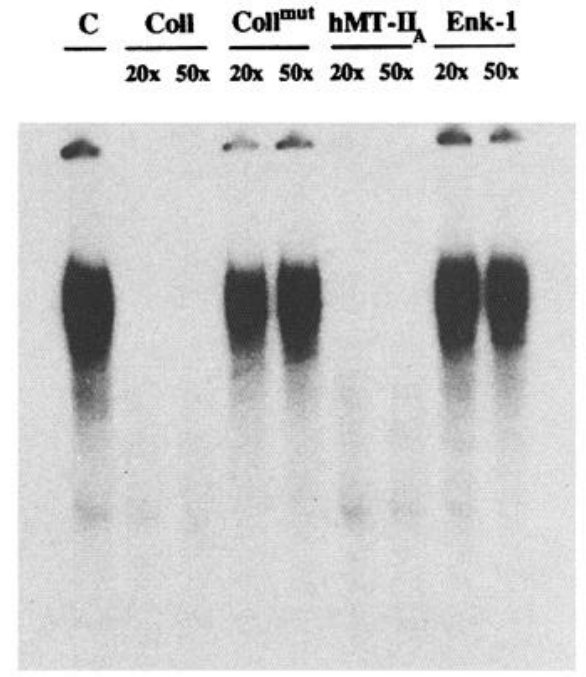

Figure 6. Increase in AP-1 binding in hippocampal nuclear extracts following kainate-induced seizures. A, Rats were sacrificed at the indicated times after an intraperitoneal injection of kainic acid $(10 \mathrm{mg} / \mathrm{kg})$. Each time point shows results from two different rats. The two bands representing AP-1 DNA-protein complexes are indicated by the arrows. B) The effects of adding a 20- or 50-fold molar excess of cold oligonucleotide containing either the collagenase AP-1 site (lanes 2, 3), a mutated collagenase AP-1 site (lanes 4, 5), an hMT- $\mathrm{II}_{\mathrm{A}}$ site (lanes 6, 7), or an Enk-1 site (lanes 8, 9) on AP-1-like binding in nuclear extracts from a $6 \mathrm{hr}$ poststimulated hippocampus.

in a biphasic manner raises the additional issue of whether both periods of gene activation have the same functional relationship to death. In an attempt to address these questions we have determined the spatial and temporal pattern of cell death and FoslacZ expression in the KA-treated rat brain. As independent indicators of cell death, nuclear morphology and DNA integrity were assessed by Hoechst 33258 staining (Oberhammer et al., 1993) and the terminal transferase biotinylated-UTP nick end labeling (TUNEL) procedure (Gavrieli et al., 1992), respectively.

TUNEL-positive neurons first became apparent at $24 \mathrm{hr}$ following administration of KA (data not shown). Thereafter, the number of TUNEL-positive cells rose dramatically to peak at 48 hr posttreatment (Fig. 7) and declined back to near basal values by $72 \mathrm{hr}$ after administration of KA. These affected neurons were located predominantly in the pyriform cortex and layers CA1 and CA3 of the hippocampus (Fig. 7). During the same time period, Fos-lacZ accumulated to maximal levels between 6 and $24 \mathrm{hr}$ posttreatment and declined back to baseline by $72 \mathrm{hr}$ although it was still readily detectable at $48 \mathrm{hr}$ in brain regions that were TUNEL-positive (Figs. 3, 4, 7). Regions of the CNS that were resistant to KA toxicity, such as the dentate gyrus, remained TUNEL negative throughout the experimental time course and did not show any protracted Fos-lacZ expression (data not shown).

While we have been unable to make the TUNEL procedure compatible with $\beta$-galactosidase histochemistry, a number of points are clear. First, since essentially all neurons in CA1 and CA3 express Fos-lacZ in the acute phase, all of the TUNELpositive cells in these regions must have experienced a cIEG response hours or days prior to DNA damage becoming detectable. Second, more neurons are Fos-lacZ positive than go on to be TUNEL-positive during the ensuing 48-72 hr. Therefore, the mere presence of Fos-lacZ in the acute phase is not an absolute indicator of subsequent cell death. However, these experiments do not establish whether the delayed period of cIEG expression, which is spatially confined to vulnerable neuronal populations and characterized by cytoplasmic Fos-lacZ, is associated with dying cells. That is, is the presence of cytoplasmic Fos-lac Z an indication of the loss of nuclear integrity and a collapse of protein trafficking a prelude to death?

To address this issue we have combined $\beta$-galactosidase histochemistry with the DNA stain, Hoechst 33258 , since the morphological changes that accompany cell death, such as condensation of chromatin and nuclear fragmentation, have been visualized using this reagent (Oberhammer et al., 1993). In Hoechst stained sections of rat hippocampus, abnormal nuclei are first observed at $48 \mathrm{hr}$ post $\mathrm{KA}$ treatment (Fig. $8 b$ ); a time that is coincident with the peak of TUNEL labeling (Fig. 7). These abnormal nuclei are characterized as being shrunken and occasionally fragmented (Fig. $8 b$, arrowheads). At both 1 and $2 \mathrm{~d}$ following KA treatment, Fos-lacZ-positive cells in CA3 appeared to have normal nuclei based upon the above criteria (Fig. 8). Thus, even though Fos-lacZ had leaked into the cytoplasm of many neurons in $\mathrm{CA} 3$, the nuclei of these cells were not detectably compromised. Those cells that had condensed nuclei did not express Fos-lacZ (Fig. $8 b$, arrowheads). There were some weakly Fos-lacZ-positive structures in CA1/CA3 that were not associated with any Hoechst fluorescence (Fig. $8 b$, open arrows). It is assumed that these apparently anuclear structures represent Fos-lacZ in dendrites of neurons whose soma was not in the section as well as the remnants of Fos-lac Z positive neurons.

While it is possible that the Fos-lacZ positive neurons observed at $48 \mathrm{hr}$ subsequently go on to die, the lack of TUNELstaining at later times suggests that these cells might survive. Indeed, since the neurons that show a protracted period of FoslacZ expression appear to have intact nuclei at $48 \mathrm{hr}$ posttreatment it may be that this highly unusual component of the cIEG response is directed at counteracting excitotoxicity.

In summary, those neurons that are sensitive to KA are induced for c-fos expression and Fos-lacZ appears with a delay in the cytoplasm of the most vulnerable populations. The presence 

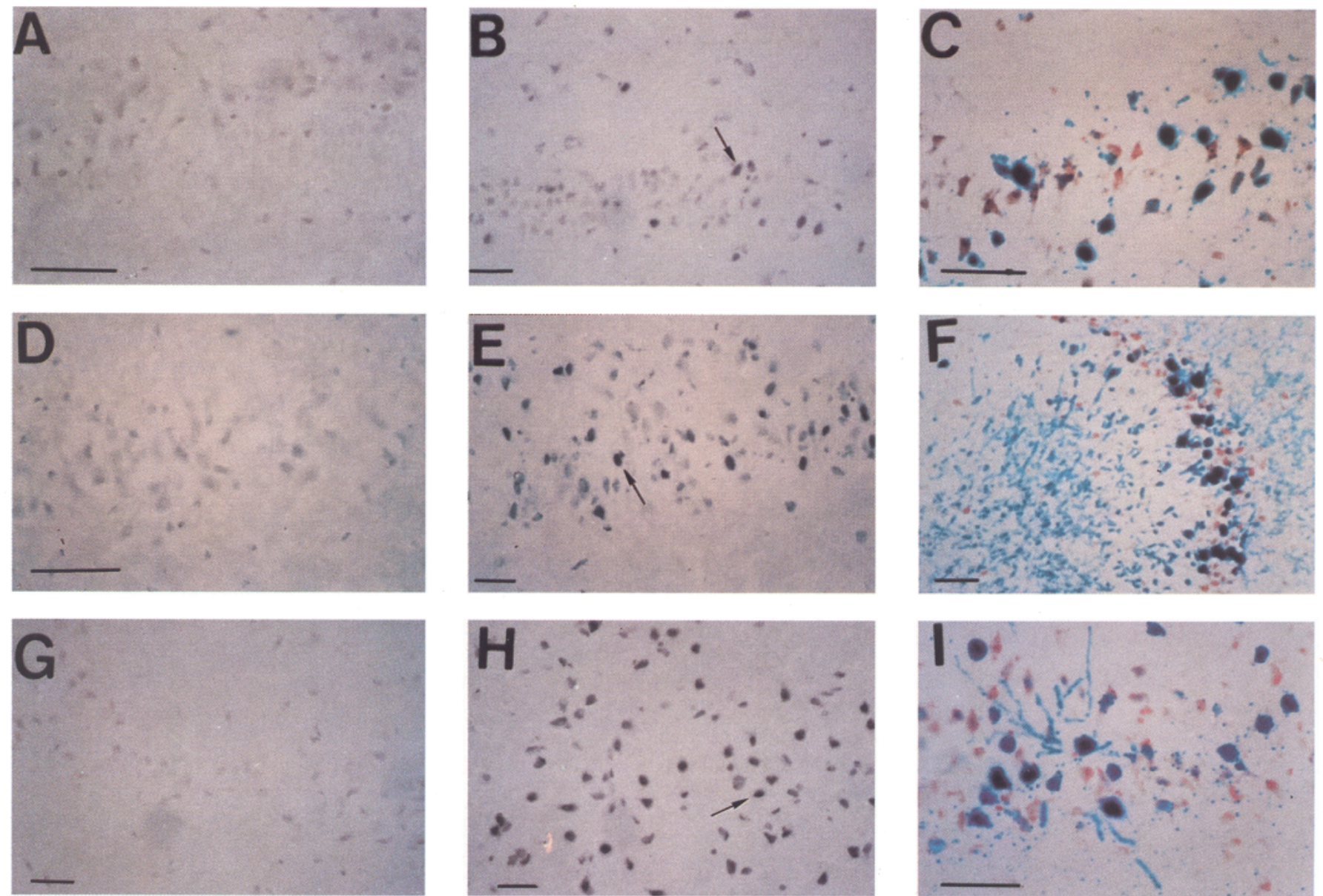

Figure 7. Kainic acid induces DNA damage in vulnerable neurons. Seizures were induced in c-fos-lacZ transgenic rats by intraperitoneal injection of KA $(10 \mathrm{mg} / \mathrm{kg})$. Rats were sacrificed at $48 \mathrm{hr}$ following treatment. $A, D$, and $G$ are from control, untreated rats. Sections are shown from hippocampal areas CA1 $(A-C)$ and CA3 $(D-F)$ and the pyriform cortex $(G-I)$. In $A, B, D, E$, $G$, and $H$ sections were stained by the TUNEL procedure in order to detect fragmented DNA. Arrows indicate TUNEL-positive neurons. $C, F$, and $I$ show sections stained for Fos-lacZ expression. Scale bars, $105 \mu \mathrm{m}$.

of Fos-lacZ in the cytoplasm precedes any overt morphological sign of nuclear damage. Since all CA3 neurons expressed FoslacZ and many subsequently died, the presence of cytoplasmic Fos-lacZ was thought to be an early harbinger of neuronal death. However, the apparently normal nuclear morphology of FoslacZ-positive cells at later times suggests that it is a reaction to the processes that lead to death. Therefore, while cytoplasmic Fos-lacZ may in some instances be an effective marker for death, it is not an absolute predictor and is not required for death. Besides c-fos, we establish that there is a complex and unique pattern of gene expression that accompanies excitotoxicity. These gene products may contribute to the biological processes associated with neuronal damage.

\section{Discussion}

A strain of c-fos-lacZ transgenic rats has been characterized in which $\beta$-galactosidase activity can be used as a simple and unambiguous measure of c-fos expression. Since the fusion gene utilizes murine c-fos genomic sequences, it is quite remarkable that this transgene accurately recapitulates both basal and inducible patterns of cognate $c$-fos expression in the rat brain. This indicates that the murine c-fos gene contains all of the transcription regulatory elements that are required for correct expression in the rat brain. Furthermore, similar signaling pathways must underlie c-fos induction in the various situations examined in this study.

While grossly similar patterns of Fos-lacZ expression were evident in transgenic rats and mice, some differences were detected. One notable example is in the caudatoputamen following administration of indirect dopamine agonists (data not shown). In general, these discrepancies were quantitative in nature and appeared to reflect species differences in c-fos expression. The c-fos-lac Z transgenic rat should prove to be a useful model for several neurobiological applications since it is more amenable to behavioral and physiological analyses than the mouse and it yields sufficient material for parallel biochemical and molecular genetic studies.

The observations made in the c-fos-lac $\mathrm{Z}$ transgenic rats raise several questions concerning the role of the cIEG response in neuronal death. For example, the induction could simply reflect a breakdown in intracellular signaling pathways. Alternatively, one or more cIEG product could fulfill a causative role in neuronal death, perhaps by regulating the expression of "suicide" genes. On the other hand, the induction of cIEGs may represent a cellular stress response that is mounted to counteract the processes set in train by the excitotoxin. Finally, the different responses may be attributable to the distinct excitatory mechanisms of KA and PTZ, rather than neuronal death per se. At this 
a
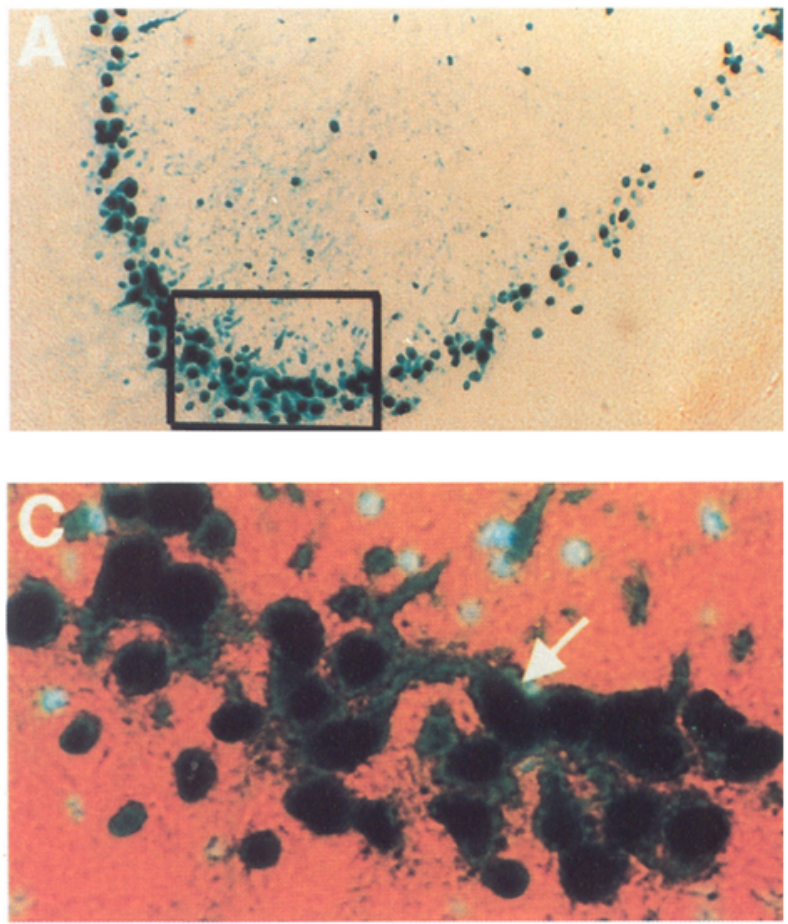

b
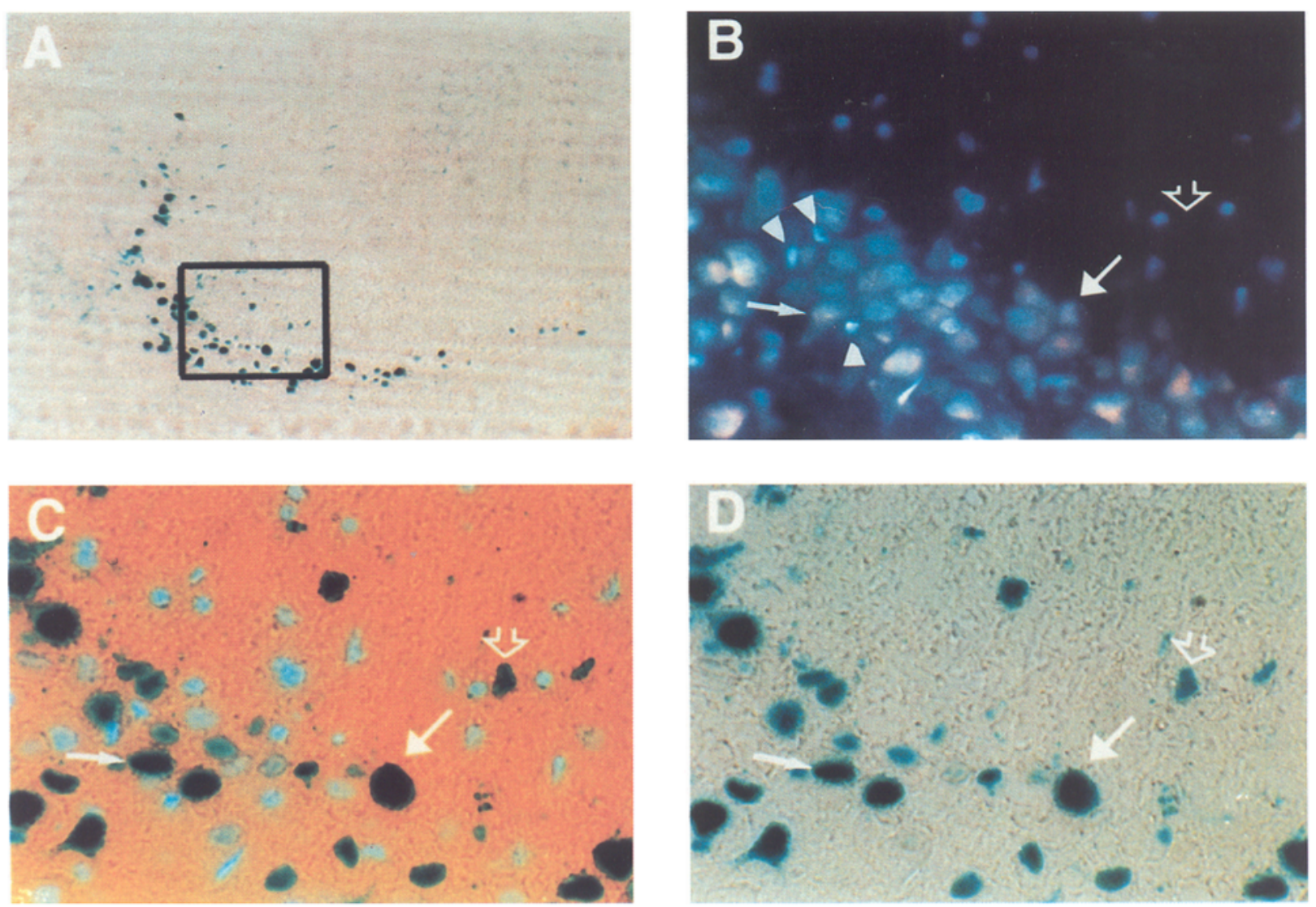

Figure 8. Morphological evaluation of Fos-lacZ positive cells using Hoechst 33258. Tissue sections from c-fos-lacZ transgenic rats $1 \mathrm{~d}(a)$ and $2 \mathrm{~d}(b)$ following KA treatment were first stained with Hoechst 33258 and then subsequently stained for Fos-lacZ. $A$ from both sets shows the FoslacZ staining in area CA3 (magnification is $10 \times$ ). Higher magnification images (40X) of the boxed region are shown in subsequent panels. $B$ shows the Hoechst stain prior to $\beta$-galactosidase histochemistry; $C$ and $D$ show the Fos-lacZ expression in the same area. $C$ was photographed under low 
level of analysis it is impossible to resolve the relationship among gene expression, mechanism of seizure activity and neuronal death, since the latter two are inextricably intertwined. Indeed, it is probable that these differences are what causes KA to be neurotoxic while PTZ is not.

In addition to the data shown here, a number of studies have pointed to an association between cIEG expression and cell death. This includes expression in many sites of programmed cell death in the developing and adult organism (Gonzales-Martin et al., 1992; Smeyne et al., 1993a,b; Marti et al., 1994). Besides these natural sites of cell death, cIEG expression has been observed in cells that have been triggered to die. For example, hormone deprivation leads to a bimodal induction of cIEGs in the prostate gland that is associated with cell death (Buttyan el al., 1988). In the nervous system, c-jun is persistently induced by treatments that result in neuronal damage such as hypoxia and status epilepticus (Dragunow et al., 1993) while focal cerebral ischemia induces c-fos, c-jun, and junB (An et al., 1992). In addition, DNA damaging agents such as UV irradiation and topoisomerase inhibitors lead to an induction of c-fos and c-jun (Devary et al., 1991; Smeyne et al., 1993a). This widespread association of cIEG expression with terminal differentiation and death would argue that the process is common to many cell types. Furthermore, since cIEG expression is detected hours or even days before overt signs of cell death appear (e.g., DNA damage) and is retained in neurons that appear to survive KA treatment (e.g., normal nuclei), it is highly unlikely that the response is caused by a catastrophic failure of intracellular signaling or homeostasis.

While the induction of the CIEG response prior to death is unlikely to be an irrelevant consequence of the collapse of signaling pathways, the association alone does not establish causation. The evidence supporting a direct involvement of cIEG products in the death process comes from experiments in which their activity was blocked. Antisense oligonucleotides to c-fos and c-jun inhibited apoptosis in lymphoid cells induced by growth factor deprivation (Colotta et al, 1992). Also in lymphoid cells, antisense oligonucleotides or transdominant suppressers to NGFI-B inhibited apoptosis (Liu et al., 1994; Woronice et al., 1994). These studies indicated that the combined function of Fos and Jun or NGFI-B were required for apoptosis. However, some of these results do not appear compatible with the finding that there is no overt disruption of programmed cell death in fos-null mice (Johnson et al., 1992, Wang et al., 1992). Furthermore, the cIEG response is triggered in many situations having nothing to do with cell death. These points, as well as the observation of persistent expression of Fos-lacZ in neurons that appear to survive KA treatment, led us to consider the possibility that clEG components are involved in a cellular stress response.

One common feature that could link the many situations in which the cIEG response is triggered is metabolic stress. For example, 2-deoxyglucose uptake, an indicator of metabolic demand, and Fos-like immunoreactivity often identify the same regions of the nervous system (Sagar et al., 1988; White and Price, 1993). This relationship would account for the induction of a cIEG response by seizures and the many agents that activate particular neuronal populations. Similar arguments can be forwarded for the many instances in which cIEGs are activated in parallel with the recruitment of quiescent cells back into the cell cycle (Greenberg and Ziff, 1984; Muller et al., 1984; Chavrier et al., 1988). However, there are other consequences of elevated metabolic demand, or compromised metabolism, such as oxidative stress, that can result in pathological conditions.

Oxidative stress is characterized by the formation of reactive oxygen intermediates that can result in damage to DNA, lipids, and proteins (reviewed in Olanow, 1993). While classically this was observed following ionizing radiation, oxidative stress is also known to occur during neurodegeneration, including that triggered by glutamate receptor agonists (Raley-Susman et al., 1992; Bondy and Lee, 1993; reviewed in Olanow, 1993). Indeed, the demonstration of DNA cleavage in hippocampal neurons following KA treatment could be one indication that these cells have suffered free radical damage.

Recently, it was shown that the binding of Fos-Jun heterodimers to DNA is sensitive to reduction-oxidation (redox; Abate et al., 1990a,b). A single cysteine residue that is conserved in the DNA binding domain of many basic-zipper superfamily members must be in a reduced, sulfhydryl, form for dimer binding to take place (Abate et al., 1990a). The predominant mole cule carrying out the reduction of this cysteine is a bifunctional enzyme, Ref-1, that is also a DNA repair enzyme possessing apurinic/apyrimidinic (AP) endonuclease activity (Xanthoudakis and Curtan, 1992; Xanthoudakis et al., 1992). In fact, Ref-I can regulate the DNA binding activity of several transcription factors, including Fos-Jun, NFKB, Myb, and members of the ATF/ CREB family (Xanthoudakis et al., 1992). Thus, the same enzyme that is responsible for repairing DNA damaged by free radicals is also capable of regulating the ability of some cIEG products to bind to DNA. It is possible that Ref- 1 plays a role in oxidative stress by coordinating both transcriptional responses to oxidative insult and the repair of damaged DNA. Both of these processes may occur during KA excitotoxicity (Raley-Susman et al., 1992; Bondy and Lee, 1993).

Several genes have been discovered that could conceivably be targets of cIEG function following oxidative stress. For example, superoxide dismutase is involved in the defense against oxygen toxicity, and mutations in one form of this gene have been linked to familial amyotrophic lateral sclerosis (ALS; Olanow, 1993). Other potential target genes include those encoding encymes involved in glutathione metabolism, some of which contain AP-1 binding sites (Morrow et al., 1990; Diccianni et al., 1992).

There are some features of the cIEG response that seem unique to situations involving excitotoxicity. First, the clEG response has two phases, an acute, transient, induction that is common to all seizures and a second, protracted, period of expression that seems unique to vulnerable neurons. Second, the spectrum of genes expressed under conditions that result in seizures and neuronal death are distinct. For example, the induction of fra- 1 and $f r a-2$ was only observed in kainic acid treated animals. The functional properties of Fra- 1 and Fra- 2 have been less ex-

light to allow covisualization of Hoechst stain and $\beta$-galactosidase. Since the Fos-lac $Z$ staining quenches the Hoechst fluorescence, one must look at $B$ to see the Hoechst staining in Fos-lacZ positive cells. Solid arrows point to examples of a Fos-lacZ-positive cells with normal nuclei. Arrowheads point to condensed nuclei which appear at 2 d following KA treatment. Open arrows indicate faint Fos-lacZ positive structures that were not associated with any Hoechst fluorescence. 
tensively studied; however, they do form AP-1 complexes with Jun and Jun family members as well as with other basic-zipper superfamily transcription factors (Hai and Curran, 1991). Therefore, it is possible that there may be a unique complement of AP- 1 complexes associated with processes leading to, or counteracting, neuronal death.

\section{References}

Abate C, Patel L, Rauscher FJ III, Curran T (1990i) Redox regulation of Fos and Jun DNA-binding activity if vitro. Science 249:11571161.

Abate C, Luk D, Gentz R, Rauscher RJ III, Curran T (1990b) Expression and purification of the leucine zipper and DNA-binding domains of Fos and Jun: both Fos and Jun contact DNA directly. Proc Natl Acad Sei $87: 1032-1036$.

An G, Lin T-N, Liu J-S, Xue J-J, He Y-Y, Hsu CY (1993) Expression of c-fos and c-jun family genes after focal cerebral ischemia. Ann Neurol 33:457-464.

Angel P, Ratumann I, Stein B, Delius H, Rahmsdorf HJ, Herrlich P (1987) 12-0-Tetradecanoyl-phorbol-13-acetate induction of the human collagenase gene is mediated by an inducible enhancer element located in the 5'flanking region. Mol Cell Biol 7:2256-2266.

Askew DS, Ashmun RA, Simmons BC, Cleveland JL (1991) Constitutive $c-m y c$ expression in an IL-3-dependent myeloid cel] line suppresses cell cycle arrest and accelerates apoptosis. Oncogene 6:19151922

Bondy SC Lee DK (1993) Oxidative stress induced by glutamate receptor agonists. Brain Rés 610:229-233.

Buttyan R, Zakeri Z, Lackshin R, Wolgemuth D (1988) Cascade induction of c-fos, c-myc, and heat shock $70 \mathrm{~K}$ trinscripts during regression of the rat ventral prostate gland. Mol Endocrinol 2:650-657.

Chavrier P, Zerial M, Lemaire P, Almendral J, Bravo R, Charnay $P$ (1988) A gene encoding a protein with zinc fingers is activated during $\mathrm{G}_{\mathrm{O}} / \mathrm{G}_{1}$ transition in cultured cells. EMBO J 7:29-35.

Cohen $\mathrm{D}$, Curran $\mathrm{T}$ (1988) fra- 7 ; a serum-inducible, cellular immediate-early gene that encodes a Fos related antigen. Mol Cell Biol 8:2063-2069.

Colotta F, Polentarutti N, Sironi M, Mantovani A (1992) Expression and involventent of $c-j o s$ and $c-j w n$ prolooncogenes in programmed cell death induced by growth factor deprivation in lymphoid cell lines. J Biol Chem 267:18278-18283.

Deutch AY, Lee MC, Gillham MH, Cameron DA, Goldstein M, Iadarola MJ (1991) Stress selectively increases Fos protein in dopamine neurons innervating the prefrontal cortex. Cereb Cortex 1:273-292.

Devary Y, Gottlieb RA, Lau LF, Karin M (199I) Rapid and preferential activation of the $c-j m$ gene during the mammalian UV response. Mol Cel] Biol 11:2804-2811

Diccianni MB, Imagawa M, Muramatsa M (1992) The dyad palidromic glutathione transferase $P$ enhancer binds multiple factors including $\Lambda$ P 1. Nucleic Acids Res 20:5153-5158.

Dragunow M, Robertson HA (1988) Localization and induction of c-fos protein-like :mmunoreactivity material in the nuclei of adult neurores. Bratin Res 440:252-260.

Dragunow M, Young D, Hughes P, MacGibbon G, Lalwlor P, Singleton K, Sirimanne E, Beilharz E, Gluckman P (1993) Is c-Jun involved in nerve cell death following status epilepticus and hypoxic-ischaemic brain injury? Mol Brain Res 18:347-352.

Evan GI, Wyllie AH, Gilbert CS, Littlewood TD, Land H, Brooks M, Waters CM, Penn LZ, Hancock DC (1992) Induction of apoptosis in fibroblasts by c-myc protein. Cell 69:119-128.

Gavrjeli Y, Sherman Y, Ben-Sasson SA (1992) Identification of programmed cell death in situ via specific labeling of nuclear DNA fragmentation. J Cell Biol I 19:493-501.

Gonzalez-Martin C, de Diego I, Crespo D, Fairen A (1992) Transient c-fos expression accompanies naturally occurring cell death in the developing interhemispheric cortex of the rat. Dev Brain Res 68:8395.

Goto K, Ishige A, Sekiguchi K, lizuka S, Sugimoto A, Yuzurihara M, Aburada M, Hosoya E, Kogure K (1990) Effects of cycloheximide on delayed neuronal death in rat hippocampus. Brain Res 534:299302.

Greenberg ME, Ziff EB (1984) Stimulation of 3T3 cells induces transcription of the c-fos proto-oncogene. Nature 311:433-437.

Hai $T$, Cuman $T(1991)$ Cross-family dimerization of transcription fac- tors Fos/Jun and ATF/CREB alters DNA binding specificity. Proc Nati Acad Sci USA 88:3720-3724.

Hammer RE, Maika SD, Richardson JA, Tang J-P, Taurog JD (1990) Spontaneous inflammatory disease in transgenic rats expressing HLA-B27 and human $b_{2}$ m: an animal model of HLA-B27-associated human diseases. Cell 63:1099-1:12.

Herdegen T, Fiallos-Estrada CE, Schmid W, Bravo R, Zimmermann M (1992) The transcription factors C-JUN, JUN D and CREB, but not FOS and KROX-24, are differentially regulated in axotomized neurons following transection of rat sciatic nerve. Mol Brain Res 14: $155-165$.

Honkaniemi J, Kainu T, Ceccatelli S, Rechardt L, Hokfelt T, PeltoHuikko M (1992) Fos and Jun in rat central amygdaloid nucleus and paraventricular nucleus after stress. Neuroreport 3:849-852.

Hope B. Kosofsky B. Hyman SE, Nestler EJ (1992) Regulation of immediate early gene expression and AP- 1 binding in the rat nucleus accumbens by chronic cocaine. Proc Natl Acad Sci USA 89:57645768 .

Johnson RS, Spiegelman BM, Papaioannou V (1992) Pleiotropic effects of a null mutation in the $c$ fos proto-oncogene. Cell 71:577580.

Kogure K, Tobita M, Sato H, Onodera H (1987) Impairment of protein synthesis in selectively vulnerable neurons. In: Cerebrovascular diseases (Raichle ME, Powers WJ, eds), pp 119-126. New York: Raven.

Kononen J, Honkaniemi J, Alho H, Koistinaho J, Iadarola M, PeltoHujkko M (1992) Fos-like immunoreactivity in the rat hypothalamic-pituitary axis after immobilization stress. Endocrinology 130: $304 l-3047$

Kure $S$, Tominaga $T_{f}$ Yoshimoto $T$, Tada $K$, Narisawa $K$ (1991) Glutamate triggers internucleosomal DNA cleavage in neuronal celis. Biochem Biophys Res Commun 179:39-45.

Imakj T, Shibasaki T, Hotta M, Demura $H$ (1993) Intracerebroventricular administration of releasing factor induces $c$-fos mRNA expression in brain regions related to stress responses: comparison with pattern of $c$-fos mRNA induction after stress. Brain Res 616:114125.

Liu Z-G, Smith SW, McLaughilin KA, Schwartz LM, Osborne BA (1994) Apoptotic signals delivered through the T-cell receptor of a T-cell hybrid require the immediate-early gene nur 77 . Nature 367 : $281-284$.

London ED, Coyle JT (1979) Specific binding of $\left[{ }^{3} \mathrm{H}\right] \mathrm{kainic}$ alcid to receptor sites in rat brain. Mol Pharmacol 15:492-505.

Marti A, Jehn B, Costello E, Keon N, Ke G, Martin F, Jaggi R (1994) Protein kinase $\mathrm{A}$ and $\mathrm{AP}-1$ (c-Fos/JunD) are induced during apoptosis of mouse mammary epithelial cells. Oncogene 9:1213-1223.

Molinar-Rode R, Smeyne RJ, Curran T, Morgan JI (1993) Regulation of proto-oncogene expression in adult and developing lungs. Mol Cell Biol 13:3213-3220.

Morgan JI, Curran T (1991) Proto-oncogene transcription factors and epilepsy. Trends Pharmacol Sci 12:343-349.

Morgan JI, Cohen DR, Hempstead JL, Curran T (1987) Mapping patterns of $c$ fos expression in the central nervous system after seizure. Science 237:192-197.

Morrow CS, Goldsmith ME, Cowan KH (1990) Regulation of human g]utathione S-transferase $\pi$ gene transcription: influence of 5 -flatnking sequences and trans-activating factors which recognize AP-Ibinding sites. Gene 88:215-225.

Muller R, Bravo R, Burckhardt J, Curran T (1984) Induction of c-fos gene and protein by growth factors precedes activation of c-myc. Nature 312:716-720.

Nadler JV, Perry BW, Cotman CW (1978) Intraventricular kainic acid preferentially destroys hippocampal pyramidal cells. Nature 271:676677.

Oberdick J, Smeyne RJ, Mann JR, Zackson S, Morgan JI (1990) A promoter that drives transgenic expression in cerebellar Purkinje and retinal bipolar neurons. Science 248:223-226.

Oberhammer F, Fritsch G, Schmied M, Pavelka M, Printz D, Lassmann H, Schulte Hermann R (1993) Condensation of the chromatin at the membrane of an apoptotic nucleus is not associated with activation of an endonuclease. J Cell Sci 104:317-326.

Olanow CW (1993) A radical hypothesis for neurodegtneration. Trends Neurosci $16: 439-144$

Popovici T, Barbin $G$, Ben-Ari $Y$ (1988) Kainic acid-induced seizures increase c-fos-like protein in the hippocampus, Eur J Pharmacol 150: $405-406$. 
Raley-Susman KM, Miller KR, Owicki JC, Sapolsky RM (1992) Effects of excitotoxin exposure on metabolic rate of primary hippocampal cultures: application of silicon microphysiometry to neurobiology. J Neurosci 12:773-780.

Represa A, Tremblay E, Ben-Ari Y (1987) Kainate binding sites in the hippocampal mossy fibers: localization and plasticity. Neurosci 20: 739-748.

Rothman SM, Olney JW (1987) Excitotoxicity and the NMDA receptor. Trends Neurosci 10:299-302.

Ryder K, Lau LF, Nathans D (1988) A gene activated by growth factors is related to the oncogene $v$-jun. Proc Natl Acad Sci 85:1487-1491.

Saffen D, Cole $\Lambda$, Worley P, Christy B, Ryder K, Baraban J (1988) Convulsant-induced increase in transcription factor messenger RNAs in rat brain. Proc Natl Acad Sci 85:7795-7799.

Sagar SM, Sharp FR, Curran T (1988) Expression of c-fos protein in brain: metabolic mapping at the cellular level. Science 240:13281331.

Schilling K, Luk D, Morgan JI, Curran T (1991) Regulation of a foslac $Z$ fusion gene: a paradigm for quantitative analysis of stimulustranscription coupling. Proc Natl Acad Sci USA 88:5665-5669.

Schreiber SS, Tocco G, Najm I, Thompson RF, Baudry M (1993) Cycloheximide prevents kainate-induced neuronal death and c-fos expression in adult rat. J Mol Neurosci 4:149-159.

Senba E, Matsunaga K, Tohyama M, Noguchi K (1993) Stress-induced c-fos expression in the rat brain: activation mechanism of sympathetic pathway. Brain Res Bull 31:329-344.

Shi Y, Glynn JM, Guilbert LJ, Cotter TG, Bissonnette RP, Green DR (1992) Role for c-myc in activation-induced apoptotic cell death in T cell hybridomas. Science 257:212-214.

Shigeno T, Yamasaki Y, Kato G, Kusaka K, Mima T, Takakura K, Graham DI, Furukawa S (1990) Reduction of delayed neuronal death by inhibition of protein synthesis. Neurosci Lett 120:117-119.

Smeyne RJ, Schilling K, Robertson L, Luk D, Oberdick J, Curran T, Morgan JI (1992) Fos-lacZ transgenic mice: mapping sites of gene induction in the central nervous system. Neuron 8:13-23.

Smeyne R.I, Vendrell M, Hayward M, Baker SJ, Miao G, Schilling K, Robertson LM, Curran T, Morgan JI (1993a) Continuous c-fos ex- pression precedes programmed cell death in vivo. Nature 363:166169.

Smeyne RJ, Schilling K, Oberdick J, Robertson L, Luk D, Curran T, Morgan JI (1993b) A fos lacZ transgenic mouse that can be used for neuroanatomic mapping. Adv Neurol 59:285-291.

Sonnenberg JL, Mitchelmore C, Macgregor-Leon PF, Hempstead J, Morgan JI, Curran T (1989a) Glutamate receptor agonists increase the expression of Fos, Fra, and AP-1 DNA binding activity in the mammalian brain. J Neurosci Res 24:72-80.

Sonnenberg JL, Macgregor-Leon PF, Curran T, Morgan JI (1989b) Dynamic alterations occur in the levels and composition of transcription factor AP-1 complexes and seizure. Neuron 3:359-365.

Sonnenberg JL, Rausher FJ III, Morgan JI, Curran T (1989c) Regulation of proenkephalin by Fos and Jun. Science 246:1622-1625.

Squires RF, Saederup E, Crawley JN, Skolnick P, Paul SM (1984) Convulsant potencies of tetrazoles are highly correlated with actions on GABA/benzodiazepine/picrotoxin receptor complexes in brain. Life Sci 35:1439-1444.

Thilman R, Xie Y, Kleihues P, Kiessling M (1986) Persistent inhibition of protein synthesis proceeds delayed neuronal death in postischemic gerbil hippocampus. Acta Neuropathol (Berl) 71:88-93.

Wang Z-Q, Ovitt C, Grigoriadis AE, Mohle-Steinlein U, Ruther U, Wagner EF (1992) Bone and haematopioetic defects in mice lacking c-fos. Nature 360:741-745.

White LE, Price JL (1993) The functional anatomy of limbic status epilepticus in the rat. I. Patterns of ${ }^{14} \mathrm{C}$-2-deoxyglucose uptake and Fos immunocytochemistry. I Neurosci 13:4787-4809.

Woronicz JD, Calnan B, Ngo V, Winoto A (1994) Requirement for the orphan steroid receptor Nur77 in apoptosis of T-cell hybridomas. Nature 367:277-281.

Xanthoudakis S, Curran T (1992) Identification and characterization of Ref-1, a nuclear protein that facilitates AP-1 DNA-binding activity. EMBO J 11:653-665.

Xanthoudakis S, Miao G, Wang FE, Pan Y-C, Curran T (1992) Redox activation of Fos-Jun DNA binding activity is mediated by a DNA repair enzyme. EMBO J 1 1:3323-3335.

Zerial M, Toschi L, Ryseck R-P, Schuermann M, Muller R, Bravo R (1989) The product of a novel growth factor activated gene, fos $B$, interacts with JUN protcins enhancing their DNA binding activity. EMBO J 8:805-813. 